\title{
THE ARRIVAL OF WHITE WOMEN: TOURISM AND THE RESHAPING OF BEACH BOYS' MASCULINITY IN ZANZIBAR
}

\author{
Altaïr Despres \\ CNRS, Institut des mondes africains - Institute of the African Worlds, Aubervilliers, \\ France; Department of Comparative Human Development, University of Chicago, \\ Chicago, IL, USA. \\ Preprint version \\ To quote this paper: Despres Altaïr (2021) The arrival of white women: Tourism and \\ the reshaping of beach boys' masculinity in Zanzibar, Ethnography, online first.
}

As is the case of many African destinations, the development of tourism in the Tanzanian archipelago of Zanzibar has been accompanied by a vehement discourse against foreign visitors. They have been accused of importing and imposing their way of life, ultimately leading to the loss of local cultural values (Sumich, 2002; Larsen, 2000). In Unguja, the archipelago's most touristic island, ${ }^{1}$ this discourse has come from political and religious authorities as well as tourism promoters who invested in the "cultural tourism" niche, with the latter having an interest in promoting the image of an authentic "spice island." Tourism is thus held responsible for the gradual disappearance of what locally represented the fundamental value of Swahili culture, which was partly fashioned by Islam. ${ }^{2}$ Many Zanzibari observers have deplored the fact that young generations frequent discos and beach parties, and no longer observe local norms for modest dress. These discourses reflect the moral struggle between competing definitions of the legitimate way to carry one's body and govern one's emotions, especially in the public sphere. On the one hand, the Muslim bodily ethos, as it was historically constructed in Swahili societies, values a certain reserve in the uses of the body. Acting with heshima (honor, respect) especially involves covering certain parts of one's body - for instance the head for women-as well as speaking softly, not becoming angry, and governing one's emotions (Beckmann, 2015; Fair, 2001). Since the arrival of mass tourism in Zanzibar, this ethos has come up against the "vacationer's habitus," which, on the contrary, is expressed through the relaxing of bodily conduct and the loosening of dress codes. ${ }^{3}$

In fact, the discourse excoriating the harmful nature of the foreign presence in Zanzibar is neither new nor specifically connected to tourism. For earlier generations, the deviant behavior of youth was alternately attributed to colonization (Pouwels, 1987) or the pernicious influence of Western and Asian films, which were accused of glamorizing lifestyles contrary to local values (Burgess, 2002; Fair, 2009). However, with the development of mass tourism, these disapproving discourses appear to have more specifically taken aim at the behavior of foreign women, and more specifically young white women who are the emblematic figures of tourism in Zanzibar. The dress, bodily, and sexual conduct of these women are at the heart of mordant moral criticism of tourism. David Parkin has recounted how during the 1990s, some religious leaders accused white women of not following Islamic precepts for modest dress, thereby threatening the piety of Zanzibari women by setting a poor example (Parkin, 1995). On leaflets Parkin examined, which were posted in front of the entrance to tourist sites, were drawn side by side a white woman and a Zanzibari woman. Above the former, dressed in a short skirt 
and a tight top, one could read the sentence "she is a whore and an infidel who dresses badly" written in Kiswahili. More recently, the government of Zanzibar published an article on the Zanzibar Aids Commission website asserting that "indecent clothing" worn by local women imitating tourists was responsible for the spread of HIV/AIDS on the island. ${ }^{4}$ Here, too, the photo illustrating the article shows two scantily clad white women alongside two Zanzibari women dressed in traditional kanga. More than the clothing, it is the sexual activity of white women that has drawn the most virulent attacks. The press, as well as many of the Zanzibaris I met, accuse white women of perverting local youth through increased sexual encounters, and even by practicing sexual tourism. ${ }^{5}$ In the field I was struck by the number of sometimes extravagant stories regarding the unreasonable sexual needs and habits of white women. On the contrary, drug abuse, alcohol consumption, and female prostitution - other scourges attributed to tourism, but more associated with white men-were discussed much less, and hardly sparked the same indignation.

The anxiety expressed in Zanzibar about the predatory sexuality of white women calls for an analysis of the social transformations to which their presence has corresponded since the advent of mass tourism in the archipelago. In what follows, I show how the intimate relationships between white women and Zanzibari men have brought into tension and sometimes redefined the practices and norms of the local sexual economy. I first look at how the arrival of white women has expanded sexual opportunities for young Zanzibaris, especially among the most disadvantaged, locally referred to as beach boys ${ }^{6}$. I then demonstrate that the massive presence of these women has disrupted the sexual segregation while publicizing overt sexuality in the public space. Finally, I examine how intimate practices with white women have challenged, and at time reshaped beach boys' masculinity in Zanzibar.

This article is based on a study conducted since 2015 in Unguja on intimate relations between white women (expatriates, occasional residents, and tourists) and local populations (Zanzibaris, migrants from Tanzania or other countries on the continent). I conducted sixty in-depth interviews on both sides with individuals who had had one-night stands, holiday romances, and long-distance affairs, as well as others who married or started a family in Zanzibar (and more rarely in Europe or the United States). I also made ethnographical observations in a number of the island's touristic areas, namely the seaside resorts of Nungwi and Kendwa (in the northwest) and Jambiani (on the east coast), as well as the capital Stone Town. I spent time on beaches, excursion sites, clubs, and private parties with tourists, expatriates, and workers in the tourism sector. This article is based primarily on materials collected from those men who are referred to in Zanzibar as beach boys. This commonly used term designates young men between the ages of 18 and 35, often from modest origins and with little schooling, who roam Zanzibar's beaches in search of tourists to whom they offer a range of goods and services at prices that are often far below those of hotels and tour operators. Some offer excursions or nautical activities, others fresh goods such as coconuts or fruit juice, yet others sunglasses, tee-shirts, and handicrafts. Upon request, beach boys can also procure drugs (essentially marijuana and cocaine), or put male vacationers in contact with prostitutes.

These young men regularly seek to establish intimate relations with female vacationers in hopes of being treated to a few drinks or a telephone, and for the most fortunate obtaining "a white ticket to Babylon"7 or becoming the associate of a tourism company created in the country with a Western partner (Author, 2017b). As I have shown elsewhere, intimate encounters between beach boys and female tourists are part of a 
continuum which includes one-night stand, holiday romance, but also marriage, longdistance conjugality, migration of the Zanzibari man to the West, and sometimes even migration of the Western partner to Zanzibar (Author, 2017a). Similar to what has been observed in other African tourist destinations, intimate relations between vacationing women and local men in Zanzibar is regularly accompanied by money or gifts given to the men (Chege, 2014; McCombes, 2012, Salomon, 2009). During their romantic affairs with women on holiday, young Zanzibari men generally acquire economic and material goods: a meal at a restaurant, the cover charge for a party, a telephone card, clothing, pack of cigarettes, and even local currency the vacationer leaves her lover upon departing. If the relationship becomes more committed, the economic transactions usually become more substantial. Women would buy a car to their lover, build them a house, pay for their tuition fees or give them money to start a business. Although they can be significant, all these economic transactions are never made explicit as consideration for a sexual service, and are often carried out with the utmost discretion so as not to publicly challenge the dominant norm of the male breadwinner - a point to which we shall return in more detail below.

It is worth noting that the involvement of Zanzibari men and women in the development of intimate relations with tourists is highly unequal. While the new sexual and conjugal opportunities offered by tourism have attracted Zanzibari men, women have generally remained at a distance. In fact, Zanzibari women have few opportunities to interact with tourists. Due to the domestic constraints that burden them as well as their reluctance to frequent sexually mixed locations, there are far fewer women than men working in the tourism sector. When they do work, they are most often employed as cooks or maids, and have less direct contact with tourists (Gössling and Schulz, 2005). As a result, it is chiefly men, with the leisure to frequent touristic sites, who have increased intimate encounters with vacationers.

\section{FEMALE TOURISTS AS UNPRECEDENTED SEXUAL OPPORTUNITIES}

While Africa only hosts approximately 5\% of the world's tourists, far behind Europe or Asia, the continent nevertheless saw sustained growth in the number of visitors during the twentieth century (UNWTO, 2016). The forecasts of the World Tourism Organization even indicate that the continent should see tourist visits double by 2030 (UNWTO, 2014). This enthusiasm for Zanzibar is in keeping with the general dynamic of tourism growth in Africa. The number of visitors more than doubled in just over ten years, rising from 125,000 in 2005 to over 300,000 in 2014. Zanzibar's tourism success is due to its geographic situation and distinctive history, which appeal to different desires for travel. Like other tropical islands in the Indian Ocean, Zanzibar has long white-sand beaches lined with coconut trees, along with turquoise water. The gentle climate also contributes to these representations of island life, making Zanzibar a leading destination for tropical seaside tourism. The natural qualities of Unguja are also joined by the prestige of its cultural heritage, which combines the memory of slavery, the Eastern influence of the Sultanate of Oman, and the spice trade. The cosmopolitan history of Zanzibar and the urban originality of its capital of Stone Town have helped drive cultural tourism, which has also been energized by the recent development of arts festivals highlighting its heritage (Bissel, 2012; Kasfir, 2004). 
Zanzibar's current success was nevertheless far from easy, for unlike other destinations in Sub-Saharan Africa that turned to tourism before independence (Dulucq, 2009), the Tanzanian archipelago long remained closed to foreign visitors. Until the 1980s, Zanzibar's socialist government limited foreign investment and trade, and severely controlled the mobility of people, capital, and goods (Keshodkar, 2013). During the 1960s, foreign visitors could not stay on the island for more than three days, and their movement was closely monitored. Officers from the Tanzania Friendship Tourist Bureau met with visitors at their point of arrival in Zanzibar, briefed them on local customs, gave them documents indicating the appropriate dress for moving about the island, and threatened them with deportation if they wore shorts or engaged in transgressive behavior with respect to local cultural and religious norms. Women were given kanga (cotton loincloth) to cover their heads, as was the custom on the archipelago, which is estimated to still be $95 \%$ Muslim today. These practices of control over tourists entirely disappeared during the 1980s. The reforms imposed by the IMF led to the liberalization of the economy and an end to socialist policies. Foreign investment increased, sparking a sudden expansion in tourist infrastructure, as well as the mass arrival of international visitors who were now free in their movement (Keshodkar, 2013).

Today Unguja is a destination that is particularly appealing to European tourists, who represent two-thirds of international arrivals. Italians are the largest contingent $(40 \%$ of the total volume of tourists), followed by Germans, the French, the British, and Scandinavians. Women have a distinctive role in this touristic flow, for unlike what has been observed for continental Tanzania, they outnumber men among visitors to the archipelago (52\% to $48 \%$ ), a gap that increases notably among younger tourists, with women representing up to $62 \%$ of visitors among the 20-24 age group (OCGS, 2014). These numbers confirm ethnographic assessments made during trips to Unguja, namely the massive presence of young white women at beaches and tourist sites. While Zanzibar is often marketed as a destination for "honeymooners," tourists travelling as couples are less common than young women travelling alone or with friends. Image 1 eloquently reflects this observation [Image 1]. I took this photograph in December 2016 at a trendy hotel in the village of Kendwa, in northwest Unguja. I was at hotel reception when a group of fifteen Norwegian women between the ages of 18 and 20 arrived. A few minutes later I saw them in their swimsuits on the beach, lounging on hotel deck chairs facing the ocean. Almost immediately, the beach boys' ballet began, each of them trying to attract the attention of the young women and engage in a conversation with them.

During the many discussions I had with the Zanzibari men who frequent tourist places, they willingly expressed their interest for white women-an interest often accompanied by a disparaging discourse toward Zanzibari women. One night, as I was dining at a restaurant with my host $\mathrm{Baraka}^{8}$ and two of his friends - all three thirtysomething Zanzibaris who had been in a couple with Scandinavian women-we talked about their romantic and married life:

Baraka: It's true that I like white women, I like skinny women. The other day, at a funeral, my cousins [women] came to me and asked me when I was going to get married. They told me that they could introduce me to some of their girlfriends. But I told them "No, I don't like locals!" Because even when they are educated, they don't see far. The only thing that matters to them is having lots of kids, driving a car and having a nice house. They don't think about traveling. That's what I like about white women, your mentality, your open-mindedness. 
On another occasion Sherif, a 35-year-old taxi driver, confided:

Sherif: With the local women, it's all lies. They lie all the time! Yeah, they can have five guys at the same time, so, you know... all lies. The locals are the worst! You go to work, they put another guy in the house. And then the local women, they don't stay long. You know, I have many friends [Zanzibaris] in Europe. They have been with their white woman for a long time. They told me: "No blacks, no sisters, it's better to have a white woman."

Anthropologist: What about you? Have you ever had an affair with a white woman? Sherif: I think everyone has had a tourist girlfriend. This is Zanzibar here! Zanzibar is the island for tourists. So if someone tells you "I've never had a tourist girlfriend," that's a lie! He's lying!

Iraj, a 32-year-old Zanzibari, also willingly told me he had dropped local women in favor of white women: "By the way, all of my friends have dated white women." However, these avowals should not be understood as signs of an effective decline in relations with local women. A number of young men I personally know actually had simultaneous relations with both white and Zanzibari women. These discourses should instead be seen as signs of normalization of the intimate relations between Zanzibari men and Western women, which is to say a diversification of the sexual and conjugal opportunities presented by the inflow of young female vacationers.

While attraction to white women is connected in the discourse of Zanzibari men to highly varying criticisms of local women (their appearance, lack of curiosity, superficiality, compulsive lying, and infidelity), it is important to compare this preference with the opportunities provided for young local men by the development of sexual and conjugal relations with Western women. The arrival of white women has provided men with a number of advantages, which are not solely limited to the moral and physical qualities they recognize in them. For Mosi, a 46-year-old Zanzibari, who in his youth was accustomed to having intimate relations with vacationers, and who humorously described himself as "Zanzibar's oldest beach boy," the arrival of white women offered young men opportunities for sexual relations freed from the logistical and moral difficulties involved in sexuality with local women:

Anthropologist: There was a lot of Zanzibari women, why would you choose white women?

Mosi: There's one thing you need to understand about Zanzibar culture. Here in Zanzibar, there's no free sex. There's no free love. For example, in Zanzibar, when you meet a [local] woman you like, the outcome is marriage entirely and directly. You have to follow the woman, to find out where she lives. And the house you saw her enter in is the house you will tell your parents: "I saw a girl in this house, I want her to be my wife." And the parents will go and propose, sometimes without the girl knowing who her future husband is. So, in those cases, having sex with her is not on the agenda! Especially for Muslims in Zanzibar.

Anthropologist: But is that true? You really don't date girls before you marry them? I'm sure you find ways...

Mosi: Yes, sometimes you stay with her for a while before you marry her. It's like your fiancée, you go for a drink once in a while...

Anthropologist: But no sex?

Mosi: No sex. Even though things are changing nowadays. But when I was young, a guy like me and other guys in my situation [from poor backgrounds] we could never have had 
a local woman, because of our culture, our rules. So, the only people we had a chance to live with were the tourists who came.

Mosi's account is a reminder that while the arrival of white women meant new sexual partners for young Zanzibari men, it has also provided access to sexuality that is more free compared to the highly controlled sexuality of local women (Beckmann, 2015), which requires dates to take place hidden from family view (especially from the young woman's family). Young lovers, who generally live with their families, thus have to find other places to meet, and maintain their relation in secret as well as they can. Conversely, sexuality with white women presents few logistical difficulties, as female vacationers often welcome their lovers in the rooms they have rented for their stay.

\section{THE SUDDEN APPEARANCE OF SEXUALITY IN THE PUBLIC SPHERE}

These new intimate relations with white women are not confined to hotel rooms, but are on the contrary displayed in the public sphere, disrupting both sexual segregation in the Zanzibari space and the heretofore obligatory norms of discretion in expressing intimacy between men and women (Larsen, 2000).

Young Zanzibari women are rare in Stone Town, with the notable exception of the areas surrounding the market. They are always covered by a kanga or a baibui, a long black garment (also called an abaya) that Muslim women commonly wear in Zanzibar on top of their clothes when they move about the city. According to Kjersti Larsen (2015), the baibui protects women's respectability, making them sexually inaccessible when they move about in public. Aside from their trips to school or work, the domestic space represents their primary place of sociability (Kingsford, 2015). On the contrary, the public sphere is highly frequented by the men who work, play football, or meet to discuss there (Loimeier, 2009). Yet with the development of tourism, vacationing women are now highly present in the street and at the beach, which until recently were occupied by men. They often conserve the summer dress codes of the West when they move about town, with their heads, shoulders, and legs uncovered. At the beach they almost systematically wear a bikini, whereas local women swim with their kanga, and men often in shorts or a tee-shirt.

By disrupting sexual segregation, the arrival of white women has led to new mixed-sex sociability in the public sphere. The streets of Stone Town and the beaches of Zanzibar are not solely places where Zanzibari men must now coexist with tourist women, they have become favored sites for interactions between them. The beach and street have become privileged sites for flirting and sociability for newly-formed couples, leading to the sudden appearance of sexuality in the public sphere. Yet unlike most local couples, those consisting of a Western woman and a Zanzibari man do not exercise great discretion regarding their intimate relation. It is common to see them kissing in public, holding hands, touching one another, or dancing suggestively when parties are organized on the beach. Whether implicit (flirting) or more explicit (touching, kissing), sexuality has taken on unprecedented visibility in spaces previously free of displays of intimacy between the sexes. While sexuality is not in and of itself taboo in the Muslim religion as it is practiced in Zanzibar, the expression of sexual desire is ordinarily reserved for the private sphere (Stiles and Thompson, 2015). In fact, Zanzibaris make a clear distinction between what can be done and said in public (hadharani), and what can be known and acknowledged in private (ndani) (Larsen, 2015). This is why eroticism, although regularly articulated in 
the public sphere, is always expressed in euphemistic or metaphorical forms, through poetry and taarab (a typical Zanzibar musical style), the sayings that appear on kanga (Beck, 2005), or through the mediation of spirits (Thompson, 2017). The norms of modesty and decency that govern interactions in the public sphere thus impose great discretion on the expression of intimate relations, sexual intimacy in particular. A couple that publicly displays its bond of intimacy (for example by holding hands or kissing in the street)-even when married-risks attracting opprobrium for themselves and their close relations (Decker, 2015). However, all of the tourists I interviewed said that they personally witnessed or experienced overt erotic games in the street and at the beach during their vacation. Observation of these spaces revealed that beach boys see white women as potential sexual partners. When they are alone, these women are quickly and systematically approached by one or more young men, who make more or less insistent attempts at engaging in flirtatious relations [Image 2].

Tourists do not simply play a passive role in these romantic games. The young women who travel to Zanzibar are quite willing to have intimate relations with local men. Engagement in the sexual act is accelerated for many of them by the distance that the tourist experience allows with respect to their ordinary network of sociability in their country of origin, thereby ensuring secret sexual encounters. A number of young women revealed that they had sexual relations "the first night" with "strangers," or with multiple sexual partners during their week on vacation. In addition to the lessening of self-control brought about by the touristic experience, these young women insist on the specific context of Zanzibar, which is simultaneously festive and romantic, and promotes quickly engaging in the sexual act. ${ }^{9}$ Dance parties organized on the beach are privileged places where Zanzibaris and Westerners flirt with one another and publicly display their sexual desires.

In addition to the physical manifestation of sexual desire, sexuality has spread to the Zanzibari public sphere through rumors regarding the lust of white women. As demonstrated by the following stories, white women are regularly described as being exhibitionist and having an immoderate sexual appetite:

One night I had a discussion with Omür, a young Turkish woman on a mission for a few months with an NGO in Zanzibar. She related the remarks of Abdalla, a Zanzibari man she knows who is the boyfriend of a white woman.

Omür: He won't stop complaining! He says she wants to make love nonstop. The other night they went to the beach, just behind the Tatu [a bar in Stone Town], and they made love. He didn't want to but she really insisted on doing it at the beach. And the next morning she wanted to do it again! She woke him up and pestered him to make love again. On another occasion, the manager of a travel agency in a hotel in Nungwi shared his exasperation during a discussion with me:

Karim: It's disgusting here. It's the kingdom of sex. It's good for your study to see this, because I think it's the worst. Worse than Tunisia, worse than Thailand, it's the worst out of everywhere I've worked!

Then, seeing one of the hotel's female clients walking by in the distance, he added:

You see her. Just yesterday, after coming back from a party, she told her husband: "Honey, I'm not tired, I'm going for a little walk on the beach and then I'll meet you." So she went there, just behind those rocks, off with a beach boy! She came back all happy five minutes later. There you have it, and it's like that all the time, you can imagine how disgusting it is. 
Such stories, which circulate widely among young Zanzibaris and spread rumors regarding the depravation of morals in Zanzibar, represent another medium through which sexuality, which is supposed to remain private, is now present in the public sphere. In the remainder of this text, I examine how sexuality with white women has challenged beach boys' masculinity.

\section{THE REVERSAL OF EXCHANGES BETWEEN THE SEXES AS AN ATTACK ON MASCULINITY?}

As mentioned above, most of the time, intimate relationships between female tourists and beach boys involve money or gifts given to the men by the women. While these transactions are rarely explicit compensation for sexual service, the beach boys who engage in these relations might be singled out for disapproval, with their promiscuity with white women being considered prostitution. One analysis of this stigmatization has been the harm caused to masculinity by economic transactions from women toward men. According to this interpretation, these young men bear the mark of emasculation and feminization, for their practices are based on a reversal of the traditional direction of exchange between the sexes.

Before discussing this interpretation through the prism of Zanzibar, it is important to come back to the terms in which masculinity has been analyzed in Africa. Most researchers agree that there is no single way to be a man. Various models of masculinity can be performed and defined according to the interactional context. Moreover, masculine normativities are contingent upon other social relations - notably class, race or generation (Morrell and Ouzgane, 2005; Lindsay and Miescher, 2003). However, a great deal of research on sexuality and conjugality in Africa has shown that sexual potency and economic power are two essential components of hegemonic masculinity (Smith, 2017; Broqua and Doquet, 2013; Biaya, 2001). The dominant norms for masculinity require men to be high sexual performers, with performance being measured by the number of conquests and duration of sexual relations. Depending on the age and status of individuals, these social expectations take different forms: multiple premarital partners, marriage, extra-marital relations, and polygamy. However, these norms for sexual power are highly connected to men's economic resources. It is socially expected from men that they comply with the "breadwinner model" and pay their intimate partner, not just in marital contexts, but in premarital and extra-marital ones as well. Married men must thus provide for the needs of their wife (or wives) - and more generally of their householdwhile lovers must compensate their partner(s) with money or gifts. These economic and material transactions connected to intimate relations are common in both Zanzibar and elsewhere in Sub-Saharan Africa (Fortier, 2004; Cole, 2004; Hunter, 2002; Poulin, 2007). They are both the expression of the man's affective engagement toward his wife, girlfriend, or female lover, as well as proof of his economic power and masculinity.

However, much research has shown that since the 1980s, the policies of structural adjustment experienced by the continent have contributed to the pauperization of a large portion of youth. For men in particular, the jump in unemployment and growing insecurity of living conditions have widely impeded their ability to fulfill social expectations in matters of masculinity. ${ }^{10}$ In many countries, the financial difficulties faced by men have led to a rising age of marriage (since they do not have the means to pay the brideprice or the expenses generated by marriage). These difficulties have an overall impact on the sexual opportunities of men, who see their ability to have sexual 
relations compromised because of their inability to directly provide money or gifts for a girlfriend.

The development of heterosexual intimate relations paid for by female tourists can therefore be seen as a reversal of the traditional order of exchanges between the sexes. It has been analyzed as an emasculation and feminization of the young African men who engage in these practices. ${ }^{11}$ George Meiu (2017), who has studied intimate relations in Kenya between young Samburu men and vacationing Western women, points out that the term "beach boy," which is used to refer to the young men who go to Mombasa to sell their charms to foreign women, functions as a dual stigma. First, calling a young Samburu man a "boy" amounts to a denial of his social maturity as a member of the "Morans" ("warriors") age class. Second, the term "beach boy"-which is the equivalent of "fag"is a fundamental challenge to the sexual potency of the person in question. By becoming the object rather than the subject of an intimate transaction (the recipient and not the giver of money or gifts), beach boys symbolically assume the dominated role of women in the structure of gender relations. Meiu also takes note of the feminization to which beach boys are subject when he relates the remarks that young Samburu women make regarding them, who mockingly refer to young men married to Western women not according to the Swahili custom-which calls for the active and male form of the verb "to marry" (anaoa, he is marrying) - but rather the passive form that is only used when the subject is a woman (anaolewa, he is being married).

Quite surprisingly, in the case of Zanzibar, most of the young men I spent time with were ostentatiously displaying their beach boy identity and relationships with Western women. First, they willingly referred to themselves as beach boys. Some of them, somewhat humorously, went as far as wearing clothing that left little doubt about their activities. At a party I met a young man wearing a t-shirt stating: "Sleep with me, free breakfast." The image that for a time served as the WhatsApp profile for one of my informants is in the same vein, showing a young man proudly wearing a t-shirt with the words "beach boy" in large print [Image 3].

In addition, the beach boys in Zanzibar voluntarily display their intimate relations with white women, about which everyone knows that they involve economic transactions to their benefit. This displaying of their conquests with women takes many forms, with the most common involving bragging about the number of their affairs (successive or simultaneous, real or fictional) with white women when discussing with friends, or posting photos with their lovers on social networks. For instance, beach boys display their successive couples with different women in their profile photos for WhatsApp. Even more conspicuously, and as we saw in the previous section, beach boys show themselves in public in the company of white women, and give signs of their intimacy by holding hands, taking their arm, kissing, dancing suggestively with them, etc. Those who have visited the streets of Stone Town and the gardens of Forodhani at sunset, or visited bars or beach parties on the east coast, have witnessed such scenes. On a number of occasions, I personally felt as though I made my informants look good. This was especially true with Ahmed, a shy young man of 18 who lived in the same neighborhood of Stone Town as I did. He made a habit of greeting me from afar by discreetly waving his hand or slightly nodding his head. During one of my trips to Zanzibar, Ahmed had his first intimate relation with a white woman. One day shortly after her departure, as I was walking down the street where he was seated at a baraza (a stone bench that traditionally surrounds homes in Zanzibar) with his friends, I was surprised to see him walking toward me with a resolute gait. As his behavior was quite unusual, to say the least, I first thought he had 
a message for me, but he simply walked up and said hello. After shaking my hand and taking me by the arm, he walked with me a few steps, before taking his leave and rejoining his friends.

Rather than a weakening of masculinity (emasculation or feminization), I argue here that the beach boys' relationships with white women should be analyzed as a reshaping of masculinity. If the toppling of the gendered order for economic transactions weakens the position of young men in the gendered hierarchy, the publicity and recognition of their intense sexual activity conversely represents proof of masculinity. In other words, one way of circumventing the stigmatization involved in intimate relations with economically more powerful women consists of (over)emphasizing another component of masculinity: the appropriation of women's bodies through sexualized interactions and sexual conquest through competition with other men in displaying these interactions to their peers. As the work of Corinne Fortier $(2004,2018)$ in Mauritania and Daniel Smith (2017) in Nigeria has clearly shown, seducing women chiefly serves as a way for men to reaffirm their masculinity by comparing themselves with one another.

\section{RESHAPING MASCULINITY TROUGH SEXUALITY WITH WHITE WOMEN}

A few days after meeting with Ahmed, I shared my surprise with Iraj regarding the young man's behavior. Iraj, who also lives in the neighborhood and knows Ahmed well, answered:

Iraj : Some young people who are growing up, I see them on the street now. They want to show that they have a white woman too. 'Cause all the brothers have white girls. I walk around with Anna [his Danish girlfriend], others have older brothers who live abroad. So, their minds become different, like ours. All the brothers who have done this [who have had relationships with white women] have made a success of their lives. So, they think, yeah, that's life! I see them on the street, like, "I want a white woman too!"

Anthropologist: So that's it, Ahmed has become a man now...

Iraj: Ahmed is the kind of kid who wants to show off now that he has a white woman too. And now that she's gone, he still wants to explore. I can see that. He's like, "Yeah, I can get girls hu!"

Iraj's words suggest that a young Zanzibari man can not only "want" a white woman, he can also want to show her, to show that he had her. Contrary to what an overly radical vision of emasculation may suggest, proving one's masculinity does not solely reside in proving one's economic power by respecting the traditional direction of exchange between the sexes. It can also be based on the ability to prove their strictly sexual power. Physical promiscuity with white women can, under certain conditions, represent an opportunity to perform masculinity.

However, in order for this game of masculinity to be worthwhile (able to ward off the specter of stigmatization that can strike beach boys at any time), it must be played out exclusively within a sanctuarized space of competition, one that includes those who recognize the virile merit of sexual conquest (peers and even female tourists), but excludes those who may have a morally disparaging view of the young men's behavior (their elders and Zanzibari women). Some of these are public spaces that have been "touristified" (beaches and downtown Stone Town in particular). Following a logic of patrimonialization specific to touristic development, these spaces are open to a foreign 
public, but gradually exclude the local populations that had occupied them previously. This game of masculinity is also present in the virtual spaces of the Internet and social media. Like tourist spaces, Facebook and WhatsApp accounts serve as spaces where beach boys publicize their intimate relations with white women, all while retaining partial control over access. The photos they post are visible to a select public essentially consisting of other young men. Like the young Mozambicans studied by Julie Soleil Archambault (2017), the use of new information and communication technologies by Zanzibar's beach boys demonstrates their ability to juggle visibility and invisibility. It is within these sanctuarized physical and virtual spaces that beach boys can publicize their sexual conquests with white women, all while reaffirming their masculinity.

In addition to being publicized, increased relations with white women can also help develop an erotic expertise that can be used on Zanzibari women. As Christian Groes (2009) has shown for young Mozambicans, the strictly sexual abilities of young men (their ability to sexually satisfy their partner) are seen as proof of their capacity to be a man. For young penniless men, who cannot express their authority over women via "the breadwinner model," demonstrating their sexual capacity is an alternative way of proving their masculinity. In Zanzibar, white women are seen as privileged partners from whom one can acquire these skills. For example, Iraj openly explained to me that his love affairs with white women clearly taught him about sex: "I learn new things every day!"; "Foreplay? We didn't know about it before!" Eros, a 27-year-old Zanzibari beach boy confirmed this erotic and educational aspect of relations with white women:

"I enjoy very much with white women. 'Cause I don't like it when we go to bed and just go straight to action. You have to take the time to do this, and this, and this [foreplay]. That's how it's good. But our girls here [Zanzibari] don't know that. That's why when I'm with white women, I feel good."

If the game of masculinity is skillfully played, relations with white women can provide young men such as Iraj, Eros, Mosi, Sherif, and Baraka with the dual advantage of both economic and sexual capital. The accumulation of this capital provides these young men with the means to achieve fulfillment through locally legitimate forms of male accomplishment. The economic bonuses and sexual skills acquired through intimate relations with white women can also be reinvested in the local sexual and conjugal economy by offering gifts to a girlfriend, paying the brideprice, supporting one's wife, and demonstrating one's know-how in sexual matters.

\section{CONCLUSION}

Image 4 is a photograph posted on WhatsApp by Eros [Image 4], which can be seen by subscribers to whom the young man granted access. The photograph was posted during Ramadan. Eros is at Nungwi beach, where he works, and is wearing a kofia, the traditional headgear that he reserves for religious use. Outside of religious celebrations, Eros prefers to wear a hat instead. Behind the man's smiling face are the outlines of three Western female tourists wearing bikinis. Without being able to establish that this staging was intentional, the contrast is immediately striking between the two symbols: the bodily asceticism called for by Ramadan (represented by the young man wearing the kofia), and the hedonism called for by tourism (represented by the partially nude young women). It is this contrast that has been singled out by many critics of tourism, who see it as a sign 
of the local culture's collapse. Many observers I interviewed were perplexed regarding this subject: why, in a country where local women are expected to cover their head and body in accordance with Islamic precepts, is nothing being done to prompt female tourists to be more modest? Why do the government of Zanzibar and civil society not more frequently condemn the behavior of vacationing women in practice? A common response emphasizes Zanzibar's economic dependence on tourism. The archipelago's GDP is dependent on the foreign currency generated by tourism, with regulation of touristic practices representing a loss of income for the local economy. The elements presented in this article offer a more complex interpretation. I have highlighted the growing economic difficulties faced by local young men, who are struggling to attain the traditional means for affirming masculinity. In a context in which acquiring a man's dominant positionordinarily through the status of husband (of one or more women) and father, which is to say a sexually active individual — is delayed, the arrival of female tourists from the West represented a boon. For these youths lacking security, tourists are particularly accessible sexual partners, thereby representing a way to display one's sexual potency while avoiding the economic obstacle. However, having more and more sexual relationships is not enough, they must be made visible to other local men, peers in particular, but hidden from local women and one's elders. Beach boys find the means to solve this paradoxical injunction in "touristified" public spaces where Western women are widely present, as well as on social media. By posting his photograph on social networks, Eros eloquently showed that young Zanzibaris can assert their Muslim faith, their participation in the transnational sexual economy linked to tourism, and their conformity to norms of masculinity.

Anthropologists have pointed out that major economic, social or political transformations tend to alter gender power relations and affect the way masculinities are experienced and imagined (Piscitelli and Simoni, 2015). In the wake of mass tourism and the economic crisis that strikes Zanzibari youth particularly hard, the beach boys, with few education, money and future prospects invest sexuality to assert their masculinity. More precisely, sexual relations with white women allow them to recompose the balance between the two traditional axes in the construction of male identity, namely economic power and sexual performance. While the economic power of Zanzibari men has suffered from capitalist globalization, sexual potency has become a key aspect of reshaping masculinity. In this regard, intimate relations with white women represent an opportunity for young men to perform a masculinity based chiefly on sexual potency, competition between men for access to women's bodies, and sexual expertise.

The examination of the processes by which the development of tourism in Zanzibar reshaped masculinity also highlights how complex logics of class, gender, and race underlie male empowerment. It helps to move beyond the now classic debate in anthropology of "sex tourism" which basically opposes two positions. On the one hand, several researchers argue that these relationships should be considered "female sex tourism" (Sanchez Taylor, 2001, 2006; Kempadoo, 2001). On the other hand, other researchers prefer to analyze them as "romance tourism" (Pruitt and Lafont, 1995; Jeffreys, 2010). There is a consensus between both sides that the "sexscapes" created by tourism in Southern countries are grounded in economic and racialized inequalities (Brennan, 2004). However, researchers who defend the "female sex tourism" position argue that, as with men, the class and racial privileges of female tourists structure their sexual encounters with local people. Within this analytical framework, they state that women are motivated by racist stereotypes of hypersexualized black men rooted in 
colonial imaginaries that lead them to objectify, fetishize and exploit black bodies ${ }^{12}$. On the contrary, proponents of the "romance tourism" approach stress that women are dominated in the sex class hierarchy and thus do not engage in the same types of exploitation that men tourists do. They insist that women engage in intimate relationships with local men within a heterosexual regime marked by male dominance and gender inequalities that has great consequences on the dynamics of these relationships, as well as on their outcomes. They show that women's sexual involvement is often associated with an emotional attachment to their partner. Additionally, as I have demonstrated in earlier work, contrary to the short-term relationships that characterizes intimacy between men tourists and local women, women tourists are often seeking long-term companionate relationships rather than mere sexual intercourse, and are likely to invest both their economic and cultural capital to the benefit of their partner's social success, eventually leading to male empowerment (Author, 2017b).

The ethnographic material presented in this paper invite to broaden the debate in new directions. I believe there is a need to pay more attention to the simultaneous presence in tourist places of two racially polarized yet equally powerful figures of sexuality that are, on the one hand, the hypersexualized black man, and on the other hand the hypersexualized white woman - an observation that has been largely overlooked so far by research on "sex tourism". While research on the colonial period has stressed that white women were denied sexual agency as they were erected as guardians of the Western civilization and public morality in the colonies, and considered potential victims of the "black peril" (Stoler, 1989; McCulloch, 2000; Pape, 1990), today's anxiety surrounding interracial sexual encounters on the contrary presents white women's sexuality as agentive, yet predatory. This calls for further analysis of how women's sexuality has served various political purposes over time, and still continues to be used as a tool to rework gender, class and race power relations.

\section{REFERENCES}

Archambault JS (2017) Mobile Secrets. Youth, intimacy and the politics of pretense in Mozambique. Chicago: University of Chicago Press.

Beck RS (2005) Texts on Textiles: Proverbiality as Characteristic of Equivocal Communication at the East African Coast (Swahili), Journal of African Cultural Studies, 17 (2): 131-160.

Beckmann N (2015) Pleasure and danger: Muslim views on sex and gender in Zanzibar. In: Stiles E and Thompson KD (eds) Gendered Lives in the Western Indian Ocean. Islam, Marriage, and Sexuality on the Swahili Coast. Athes: Ohio University Press, pp. 117140.

Biaya TK (2001) Les plaisirs de la ville: Masculinité, sexualité et féminité à Dakar (19972000). African Studies Review 44 (2): 71-85.

Bissell W (2012) From Dhow culture to the Diaspora: ZIFF, Film, and the Framing of Transnational Imaginaries in the Western Indian Ocean. Social Dynamics 38 (3): 479498.

Brennan D (2004) What's Love Got to Do with it? Transnational desires and sex tourism in the Dominican Republic. Durham, NC: Duke University Press. 
Broqua C and Doquet A (2013) Penser les masculinités en Afrique et au-delà. Cahiers d'études africaines, 209-210: 9-41.

Burgess T (2002) Cinema, bell bottoms, and miniskirts: struggle over youth and citizenship in revolutionary Zanzibar. International Journal of African Historical Studies 35 (2-3): 287-313.

Chege N (2014) Male Beach Workers and Western Female Tourists: livelihood strategies in Kenya's south coast region. PhD Thesis, Université de Lausanne, Switzerland.

Coëffé V et al. (2016) Mens sana in corpore turistico: le corps "dé-routinisé" au prisme des pratiques touristiques. L'information géographique, 2 (1): 32-55.

Cole J (2004) Fresh contact in Tamatave, Madagascar: sex, money and intergenerational transformation. American Ethnologist, 31 (4): 573-588.

Cole J (2005) The Jaombilo of Tamatave, Madagascar. Journal of Social History 38 (4): 891-914.

Decker C (2015) Love and sex in Islamic Africa: introduction. Africa Today, 61 (4): 110.

Despres A (2017a) 'Venues pour les plages, restées pour les garçons'? Du tourisme à l'expatriation amoureuse des femmes a`Zanzibar. Recherches Familiales 14: 67-78.

Despres A (2017b) Des histoires avec lendemains. Intimité transnationale et ascension sociale des beach boys de Zanzibar. Actes de la recherche en sciences sociales 218: 8299.

Dulucq S (2009) 'Découvrir l'âme africaine'. Les temps obscurs du tourisme culturel en Afrique coloniale française (années 1920-années 1950). Cahiers d'études africaines 193194: 27-48.

Ebron P (1996) Traffic in men. In Grosz-Ngate M and Kokole O (eds) Gendered Encounters: challenging cultural boundaries and social hierarchies in Africa. New York and London: Routledge, pp. 223-244.

Fair L (2001) Pastimes and Politics. Culture, community, and identity in post-abolition urban Zanzibar, 1890-1945. Athens: Ohio University Press.

Fair L (2009) Making love in the Indian Ocean. Hindi films, Zanzibari audiences, and the construction of romance in the 1950s and 1960s. In: Cole J and Thomas L (eds) Love in Africa. Chicago: Chicago University Press, pp. 58-82..

Fortier C (2004) «Séduction, jalousie et défi entre hommes. Chorégraphie des affects et des corps dans la société maure ». In: Héritier F et Xanthakou M (eds.), Corps et affects. Paris: Odile Jacob, pp. 237-254

Fortier C (2018) The expenses of love: seduction, poetry and jealousy in Mauritania. In: Fortier C, Kreil A and Maffi I (eds) Reinventing Love? Gender, intimacy and romance in the Arab world, Peter Lang, pp. 49-69.

Grange Omokaro F (2014) Monétarisation de la sexualité et des sentiments en Afrique. In: Broqua C and Deschamps C (eds) L'échange économico-sexuel. Paris: Éditions de l'EHESS, pp. 153-170. 
Groes-Green C (2009) Hegemonic and subordinated masculinities: class, violence and sexual performance among young Mozambican men. Nordic journal of African studies 18 (4): 286-304.

Gössling S and Schulz U (2005) Tourism-related migration in Zanzibar, Tanzania. Tourism Geographies: an international journal of tourism space, place and environment 7 (1): 43-62.

Granger C (2017) La saison des apparences. Paris: Anamosa.

hooks B (2004) We real cool: Black men and masculinity. New York City: Routledge.

Hunter M (2002) The Materiality of Everyday Sex: Thinking beyond 'Prostitution.' African Studies 61 (1): 99-120.

Hunter M (2005) Cultural Politics and Masculinities: Multiple-Partners in Historical Perspective in KwaZulu Natal. Culture, Health \& Sexuality 7 (4), 389-403.

Jeffreys S (2010) Sex tourism: do women do it too? Leisure Studies, 22 (3): 223-238.

Kasfir SL (2004) Tourist Aesthetics in the Global Flow: orientalism and 'warrior theatre' on the Swahili Coast. Visual Anthropology 17: 319-343.

Kempadoo K (2001) Freelancers, Temporary Wives, and Beach-Boys: Researching Sex Work in the Caribbean. Feminist Review, 67: 39-62.

Keshodkar A (2013) Tourism and Social Change in Post-Socialist Zanzibar. Struggle for identity, movement and civilization. Lanham: Lexington Books.

Kimmel M and Plante R (2005) The gender of desire. The sexual fantasies of women and men. In: Kimmel M (ed) The Gender of Desire. Essays on male sexuality. New York: State University of New York Press, pp. 45-64.

Kingsford K (2015) Learning to be a Woman: negotiating gender and identity in Zanzibar. $\mathrm{PhD}$ Thesis, University College London, United Kingdom.

Larsen K (2000) The Other Side of 'Nature': expanding tourism, changing landscapes, and problems of privacy in urban Zanzibar. In: Broch-Due V and Schroeder RA (eds) Producing Nature and Poverty in Africa. Stockholm: Nordiska Afrikainstitutet, pp. 198219.

Larsen K (2015) Pleasure and prohibitions. Reflections on gender, knowledge, and sexuality in Zanzibar Town. In: Stiles E and Thompson KD (eds) Gendered Lives in the Western Indian Ocean. Islam, Marriage, and Sexuality on the Swahili Coast. Athens: Ohio University Press, pp. 209-241.

Le Guennec-Coppens F (2002) Les Swahili: une singularité anthropologique en Afrique de l'Est. Journal des Africanistes 72 (2): 55-70.

Lindsay L and Miescher S (2003). Men and Masculinities in Modern Africa. Portsmouth, NH: Heineman.

Loimeier R (2009) The Baraza: A grass-roots institution in East Africa. In : Fourchard L and Goerg $\mathrm{O}$ (eds) Les Lieux de sociabilité urbaines dans la longue durée en Afrique, Paris: Karthala, pp. 171-190.

McClintock A (1995) Imperial Leather: Race, Gender and Sexuality in the Colonial Contest. New York and London: Routledge. 
McCombes L (2012) Host-guest encounters in a Gambian 'love' bubble. In: van Beek W and Schmidt A (eds) African Hosts and their Guests. Cultural Dynamics of Tourism. Rochester: James Currey, pp. 290-315.

McCulloch J (2000) Black Peril, White Virtue: Sexual Crime in Southern Rhodesia, 1902-1935. Bloomington: Indiana University Press.

Masquelier A (2005) The Scorpion's sting: youth, marriage and the struggle for social maturity in Niger. Journal of the Royal Anthropological Institute 11 (1): 59-83.

Meiu G (2017) Ethno-erotic Economies. Sexuality, money and belonging in Kenya. Chicago: University of Chicago Press.

Morrell R and Ouzgane L (eds) (2005) African Masculinities: Men in Africa from the Late Nineteenth Century to the Present. New York: Palgrave MacMillan.

Nyanzi S et al (2005) Bumsters, big black organs and old white gold: embodied racial myths in sexual relationships of Gambian beach boys. Culture, Health \& Sexuality 7 (6): 557-569.

Office of the Chief Government Statistician (OcGS) (2014) Zanzibar Socio-Economic Survey, 2014, Preliminary Statistical Report, May.

Pape J (1990) Black and White: The 'Perils of Sex' in Colonial Zimbabwe. Journal of Southern African Studies, 16 (4): 699-720.

Parkin D (1995) Blank banners and Islamic consciousness in Zanzibar. In: Cohen A and Rapport N (eds) Questions of Consciousness. London: Routledge, pp. 198-216.

Piscitelli A and Simoni V (2015) "Masculinities in times of uncertainty and change: introduction", etnográfica, 19 (2): 293-299.

Poulin M (2007) Sex, money, and premarital partnerships in Southern Malawi. Social Science and Medicine, 65 (11): 2383-93.

Pouwels RL (1987) Horn and Crescent. Cultural change and traditional Islam on the East African Coast, 800-1900. Cambridge: Cambridge University Press.

Pruitt D and Lafont S (1995) For love and money. Romance Tourism in Jamaica. Annals of Tourism Research, 22 (2): 422-440.

Salomon C (2009) Antiquaires et businessmen de la Petite Côte du Sénégal. Le commerce des illusions amoureuses. Cahiers d'études africaines, 193-194: 147-173.

Sanchez Taylor J (2001) Dollars are a Girl's Best Friend? Female tourists' Sexual Behavior in the Caribbean. Sociology, 35 (3):749-764.

Sanchez Taylor J (2006) Female Sex Tourism: A Contradiction in Terms? Feminist Review, 83 (1): 42-59.

Selänniemi T (2003) On holiday in the liminoid playground: place, time, and self in tourism. In: Bauer T and McKercher B (eds) Sex and Tourism: journeys of romance, love and lust. Binghampton, New York: The Haworth Press, pp. 19-31.

Sheriff A (2010) Dhow Cultures and the Indian Ocean: cosmopolitanism, commerce and Islam. New York: Columbia University Press. 
Silberschmidt M (2005) Poverty, male disempowerment, and male sexuality: rethinking men and masculinities in rural and urban East Africa. In: Ouzgane L and Morrell R (eds) African masculinities. Men in Africa from the late Nineteenth Century to the Present. New York: Palgrave Macmillan, pp. 189-203.

Smith DJ (2017) To Be a Man Is Not a One-Day Job: masculinity, money and intimacy in Nigeria. Chicago: University of Chicago Press.

Stiles E and Thompson K (eds) (2015) Gendered Lives in the Western Indian Ocean. Islam, marriage, and sexuality on the Swahili Coast. Athens: Ohio University Press.

Stoler AL (1989) Making Empire respectable: the politics of race and sexual morality in twentieth century colonial cultures. American ethnologist, 16 (4), 634-660.

Sumich J (2002) Looking for the 'other': tourism, power, and identity in Zanzibar. Anthropology Southern Africa 25 (1-2): 39-45.

Thompson K (2017) Popobawa. Tanzanian Talk, Global Misreadings. Bloomington: Indiana University Press.

United Nation World Tourism Organization (UnwTO) (2014) Tourism in Africa: a tool for development, Affiliate Members Regional Reports, Volume four.

United Nation World Tourism Organization (UNWTO) (2016) Faits saillants OMT $d u$ tourisme.

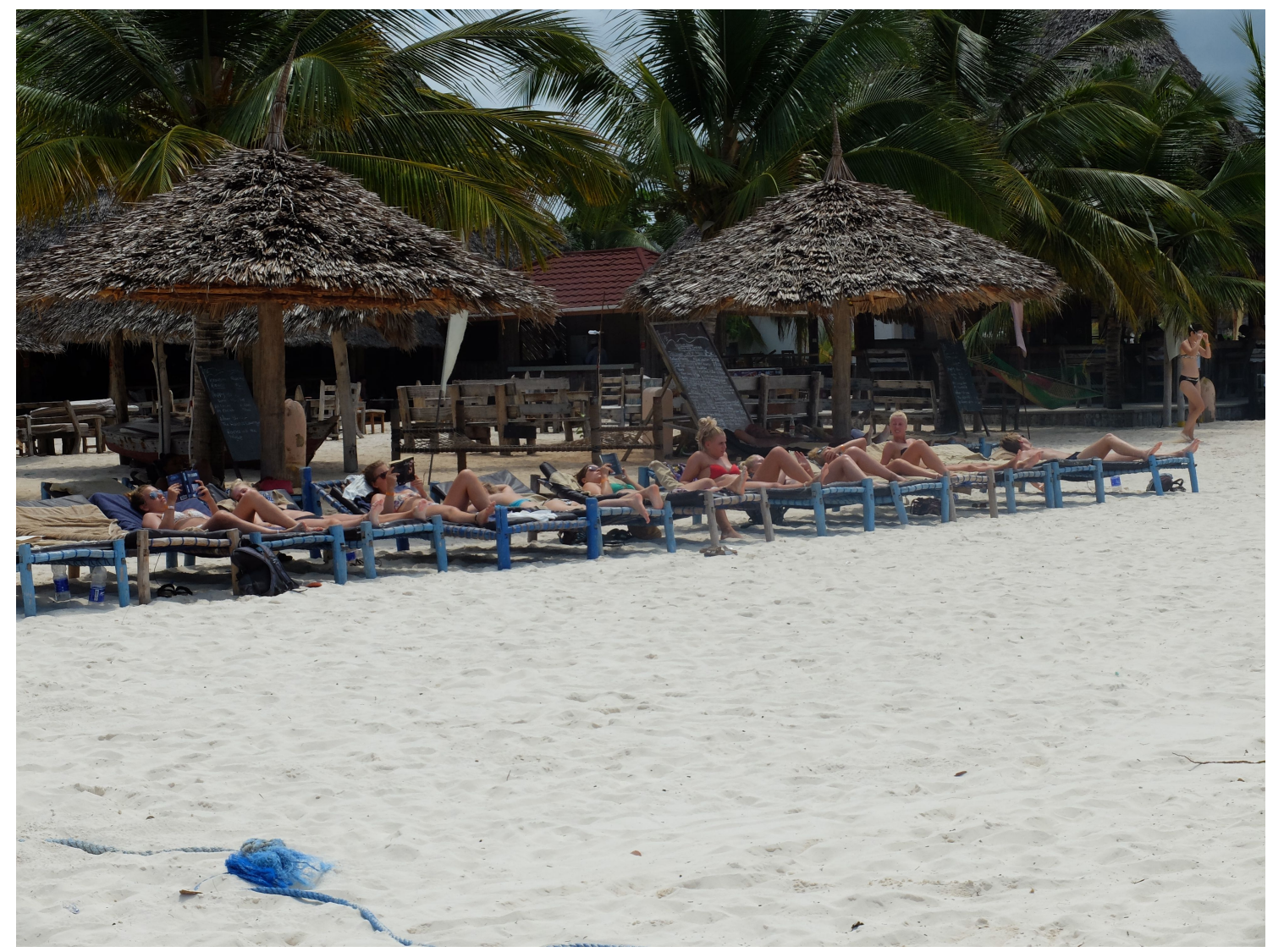

Image 1: Group of fifteen young Norwegian women at Kendwa Beach in northwest Zanzibar (Despres, 2016) 


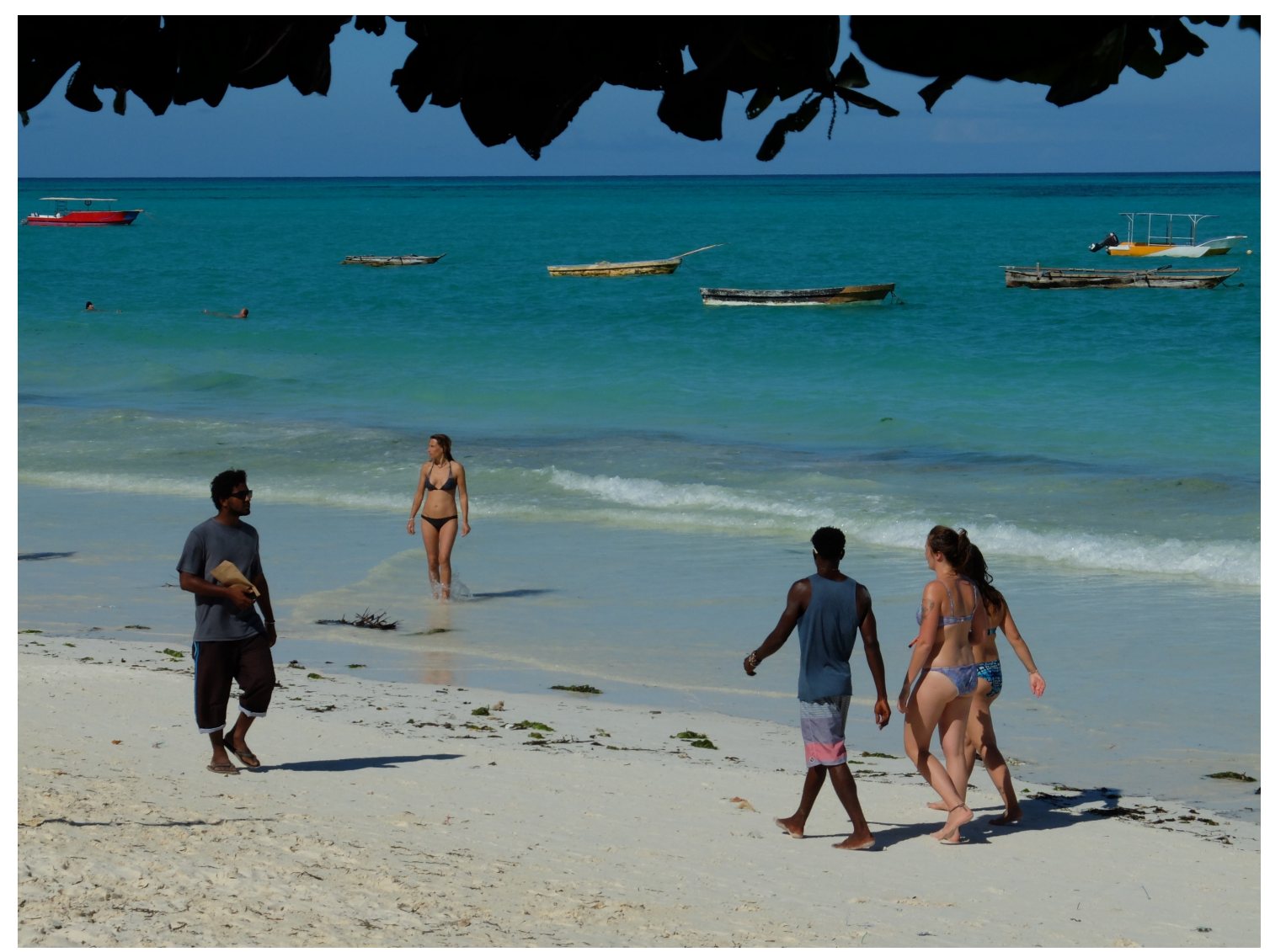

Image 2: Beach boy approaching tourists on Paje Beach (east coast of Zanzibar) (Despres, 2019)

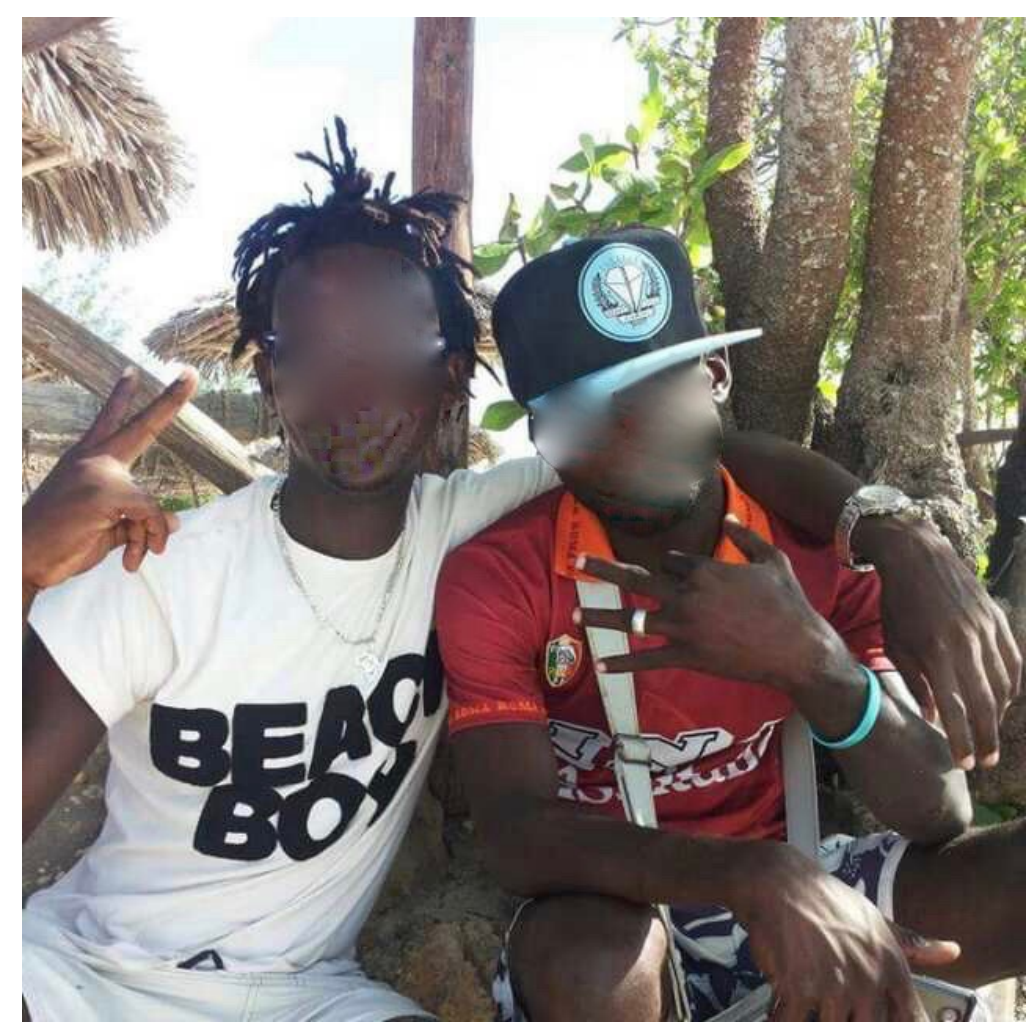

Image 3: WhatsApp profile photo of a Zanzibari beach boy (Anonymous, 2016) 


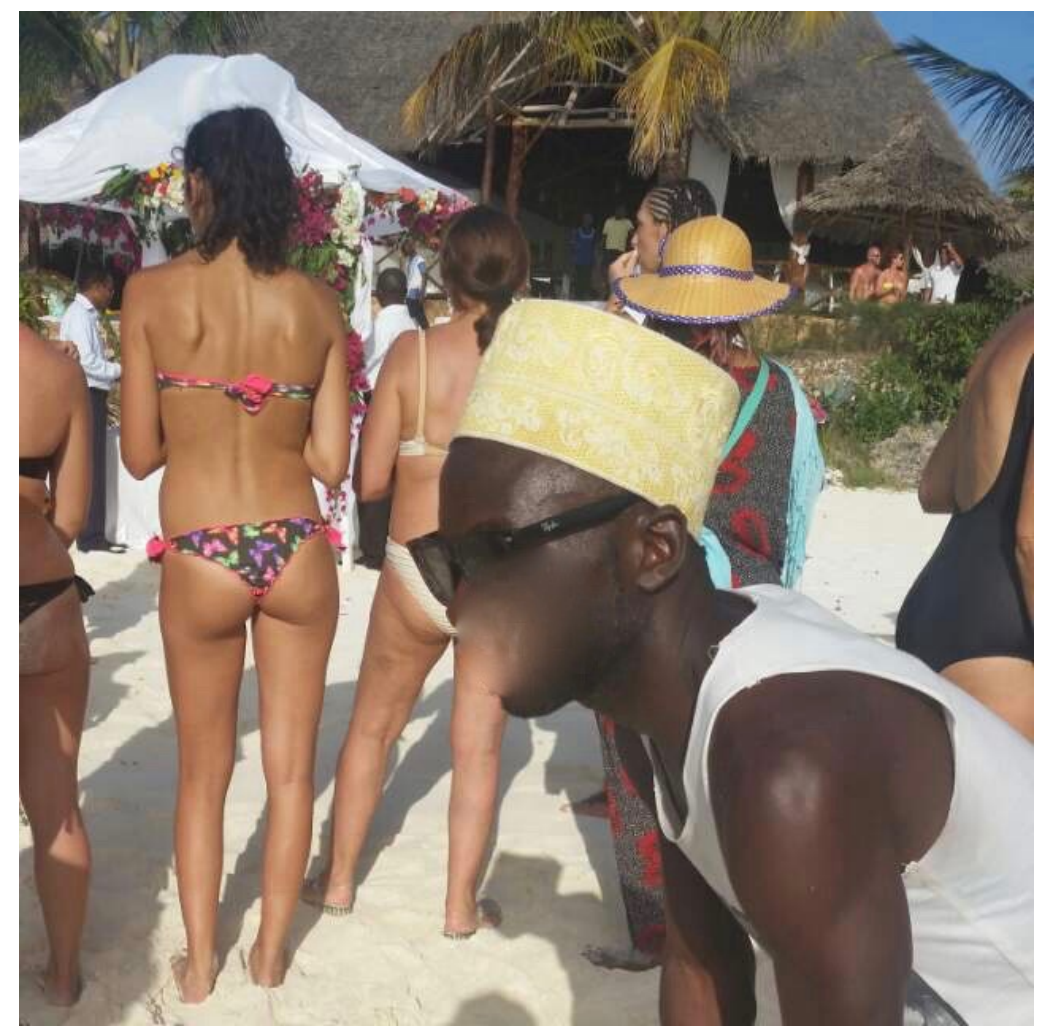

Image 4: WhatsApp profile photo posted during Ramadan by Eros (Anonymous, 2016)

\section{AKNOWLEDGMENTS}

This project has received funding from the European Union's Horizon 2020 research and innovation programme under the Marie Skłodowska-Curie grant agreement No 795681. The materials used in this article were gathered during various research trips to Zanzibar made possible by support from other institutions: the European Centre of Sociology and Political Science (CESSP), GIS-Genre, IFRA-Nairobi, and the Labex TransferS. I would like to thank the individuals with whom I spoke in Zanzibar for their dedication and indulgence toward this research. I would like to extend a special thanks to my Swahili professor Ali Khamis Shaali (Mwalimu Ali), who often played the role of research assistant. My thanks also go out to the participants in the "Zanzibar: showing/hiding, saying/keeping quiet, and other (false) secrets" workshop held in 2018 at EHESS and Université Paris Nanterre, participants in the African Studies Workshop (ASW) at the University of Chicago, and the students in the Ethnographic writing course taught by Jennifer Cole in 2018-2019, who provided helpful comments on earlier versions of this article. I would also like to thank the reviewers for their useful suggestions and critiques. Lastly, I would like to thank Wilfried Lignier for his invaluable comments and advice on this paper. 


\footnotetext{
${ }^{1}$ Zanzibar is made up of three primary islands: Unguja, Pemba, and Mafia. Most investments in tourism were made in Unguja, which is the island people often refer to when speaking of the "island" of Zanzibar.

${ }^{2}$ What is today referred to as the Swahili population was formed by commercial contacts between coastal populations in East Africa (from southern Somalia to northern Mozambique, including nearby islands) and Arab merchants from the tenth century onward, along with the marriages that united these populations. This coastal population shares both a language, Kiswahili, and a religion, Islam (Le Guennec-Coppens, 2002; Sheriff, 2010).

${ }^{3}$ Following Norbert Elias, some authors have shown that the "de-routinization" that characterizes the tourism experience involves a relaxation of daily constraints, thereby influencing the bodily and emotional behavior of tourists (Coëffé et al. 2016; Selänniemi, 2003). For a sociohistory of bodily practices during the summer (in a Western context), see also Granger 2017.

${ }^{4}$ Zanzibar Aids Commission: "Wanawake watakiwa kuvaa nguo zenye heshima" ("Women are asked to dress respectfully") $<$ http://www.zac.or.tz/news/swahili-news/2-wanawake-watakiwa-kuvaa-nguo-zenyeheshima>, accessed on February 19, 2018.

${ }^{5}$ See for example, "Zanzibar: Where women come to buy sex," published on May 8, 2016 on Mzalendo.net $<$ https://www.mzalendo.net/makala/zanzibar-women-come-buy-sex.html>, accessed on April 15, 2019.

${ }^{6}$ In this article I focus on the case of beach boys, a group of young men characterized by a low level of education and income. However, the social transformations analyzed in this text have also had an impact on other more privileged male groups (students, young professionals, cultural elites), albeit in a less crucial way.

${ }^{7}$ The metaphor refers to the possibility of migrating toward the North, often by marrying a tourist. Cited by Nyanzi 2005.

${ }^{8}$ All names (including pseudonyms) have been modified to maintain the anonymity of those interviewed.

${ }^{9}$ It is revealing that in the discourses of Western women regarding their fantasies, the setting occupies a central role. In particular, making love on the beach in a romantic setting is a recurring fantasy (Kimmel and Plante, 2005).

${ }^{10}$ For Kenya and Tanzania see Silberschmidt 2005, for Madagascar see Cole 2005, for South Africa see Hunter 2005, for Mali see Grange Omokaro 2014, for Mozambique see Groes-Green 2009, and for Niger see Masquelier 2005.

${ }^{11}$ Paulla Ebron (1997), who has worked on the Gambia, even believes that transactions between beach boys and tourists, insofar as they materialize unequal power relations between Northern and Southern countries, embody the emasculation of the entire country.

${ }^{12}$ On the social and historical construction of Black men's hypersexuality, see hooks, 2004; McClintock, 1995.
} 